\title{
LOCAL LITERATURE AND CHILD CHARACTER DEVELOPMENT
}

\author{
Martha Maspaitella ${ }^{*}$, Betsi Rooroh, Adisti Primi Wulan \\ (FKIP Pattimura University, Indonesia) \\ (Manado State Polytechnic, Indonesia.) \\ (IKIP PGRI Pontianak, West Kalimantan, Indonesia.)
}

\begin{tabular}{|c|c|}
\hline A R T I C L E I N F O & A B S T R A C T \\
\hline $\begin{array}{l}\text { Keyword: } \\
\text { Assessment as learning, } \\
\text { critical thinking, creative } \\
\text { thinking, problem-solving }\end{array}$ & $\begin{array}{l}\text { This study describes the relationship of local literature and children's character, with } \\
\text { the anecdotal text of the Kiud as the source of the study. The results show that not } \\
\text { only serious children's literature is loaded with character education but ridiculous and } \\
\text { funny anecdotal texts also shape the character of the child. These character values } \\
\text { become a force that enables children to behave appropriately in various social } \\
\text { situations }\end{array}$ \\
\hline
\end{tabular}

\section{INTRODUCTION}

Character education is developed to teach children about the important qualities needed to build good character, and help them become members of a democratic society, responsible, respectful, and contribute, and encourage the development of their ethical and pro-social motivations and competencies (Chandra \& Suyitno, 2017). In other words, character education can meet students' social, emotional, and cognitive needs (Almerico, (2014: 2; White and Warfa, 2011: 45; Berkowitz and Hoppe. 2009: 131).

A good character is what a leader and coworker look for; what parents look for in their children; what you are looking for in their brothers and sisters; and what you are looking for between one friend and another. So, good character is the center of the welfare of individuals and society. When a child is able to understand and apply good character values in his life, then the character becomes a strength, as well as a strong foundation and manifests in his thoughts, feelings, and behavior (Quinlan, Swain, and Brodrick, 2012: 1145-1146; Park, 2009: 42).

According to Albertus (2012: 53-57), all the meanings about character education put forward must be related to the formation of human beings. Therefore, its definition and understanding must be in harmony and consistent with understanding, and the underlying anthropology. That is, character education is not only understood as a process of socializing manners and manners in society but more than the introduction and practical politeness in society. Character education is a conscious human effort to develop the entire interpersonal relational dynamics with various dimensions, both from within and from outside themselves so that the person can increasingly live out his freedom, so that he can be more responsible for his own growth as a person and the development of others in life they are based on moral values that respect human dignity.

From the explanation, it was concluded that character education can be obtained outside of formal education. One medium that can shape children's character is folktale as local literature by giving values as a habit or tradition of educating, even though the delivery is done orally. This is in accordance with

\footnotetext{
* Corresponding author.

E-mail addresses: marthamaspaitella2017@gmail.com (Martha Maspaitella), betsi.rooroh@polimdo.ac.id (Betsi Rooroh), adistiprimiwulan@ikippgri.ac.id (Adisti Primi Wulan)
}

ISSN : 2597-7385 (Online) - ISLLAC : Journal of Intensive Studies on Language, Literature, Art, and Culture is licensed under Creative Commons Attribution-ShareAlike 4.0 International License (http://creativecommons.org/licenses/BY/4.0/). 
Sibarani's opinion (2012: 4) which states that cultural traditions in ancient times were inherited verbally by ancestors.

The term Folklore was first introduced by William Thompson in 1846, through the words folk and lore. Folks is people or collectives who share the same physical identification or culture. Lore is folk knowledge or tradition which is part of a culture that has been passed down through generations orally, with reminders. Lore is also a representation of folk wishes and expressions (Noyes, 2012: 13; Danandjaja, 1994: 1-2).

Folklore is defined as material sent orally because it is spoken in words or delivered by word of mouth. This term is the basis for oral formulaic and oral literature studies. Therefore, folklore gives meaning terminology, such as oral tradition, oral literature, oral narrative, oral testimony, etc (Finnegan, 1992: 5).

Folklore is an oral expression of traditional culture that can connect the owner community with the past and future. Folklore is also an important expressive component in the lives of all ongoing human groups. This study is very broad because as a cultural practice, there are several ways shaped by expressive power. A number of folklore phenomena, such as traditional cultural expressions, are related to the context and circumstances in which things, events or creative expressions are understood as folklore revealed or manifested in space and time (Zuhdi, 2015:63; Bendix dan Rokem, 2012: 9-12; Brunvand, 1996:3).

The term folklore often covers many topics, and sometimes has a broad meaning for all forms of tradition that are transmitted orally, including material culture, and verbal forms such as stories and songs, and specifically emphasized the collection or analysis of texts (Finnegan, 2005:10). But in this article, it is focused on folktale or folklore in the folklore as a collective wealth of a society to bring up some of its culture which is still stored as a collective memory of the history that actually happened or is just a myth. Thus, whether a folktale is true or not is acceptable in the context of the life of its owner. As a listener or reader, even though more interpretation is needed to interpret a local story, it still has to accept it as a cultural product as well as the cultural richness of a traditional society that helps shape the character of the community of its owner.

The study of anecdotal texts has been carried out by many researchers, but more so on the ability to write anecdotal texts and text structures with political themes. Among them are Sugiantomas and Damayanti (2017), Rahmayanti, Martha, and Wisudariani (2015), but exposure to aspects of silliness including the relationship of anecdotal texts to the formation of child character has not been done yet.

Anecdotal text needs to be studied to shape the character of the child because it includes reading that is light or does not drain children's thoughts and bores, but is fun because there are humorous elements from aspects of silliness and humor in anecdotal stories. The contents of the text contain character values that are social criticism that must be interpreted holistically starting from the structure, aspects of silliness, and the value of the character. Therefore, in this article, we will describe anecdotal text structures, representations of aspects of silliness and humor in anecdotal texts, and character values in anecdotal texts.

\section{METHOD}

This type of research is qualitative with the descript method, which is a research method used by researchers to describe or describe the relationship of local literature with children's character through the development of inductive mindset. So, the problem of this research does not have to be based on theory, axioms, and principles as existing truths, but based on facts that exist and appear in the field (Heryadi, 2010: 37). Research data in the form of units of ideas obtained from the anecdotal text Kiud from Southwest Maluku. In the book The Types of The Folktale, Anti Aarne and Stith Thompson (see Danandjaja, 1994: 86), have divided the types of fairy tales into four major groups, namely (1) animal fables, (2) ordinary fables, (3) jokes and anecdotes, (4) fairy tale.

The procedure that is passed from data retrieval to the meaning of data is:

a) Repeatedly reading the entire anecdotal text of the Kiud,

b) Determine the parts of the text according to the anecdotal text structure,

c) Record the units of ideas that contain ridiculous and funny things,

d) Describe the anecdotal text structure of the Kiud, 
e) Describe representations of silliness and humor in the text

e) Explain character values that are the strength to shape the character of the child.

Data analysis is based on the interactive analysis process of Miles and Huberman (1992: 16-20), namely the process of collecting data, reducing, presenting data, and verifying.

\section{RESULTS AND DISCUSSION}

According to Bazerman (2005: 45), anecdotal texts are included in pleasant themed texts that have a complicated and memorable sequence of events that have not been resolved but are used to share feelings. The mapping can be seen in the following picture.

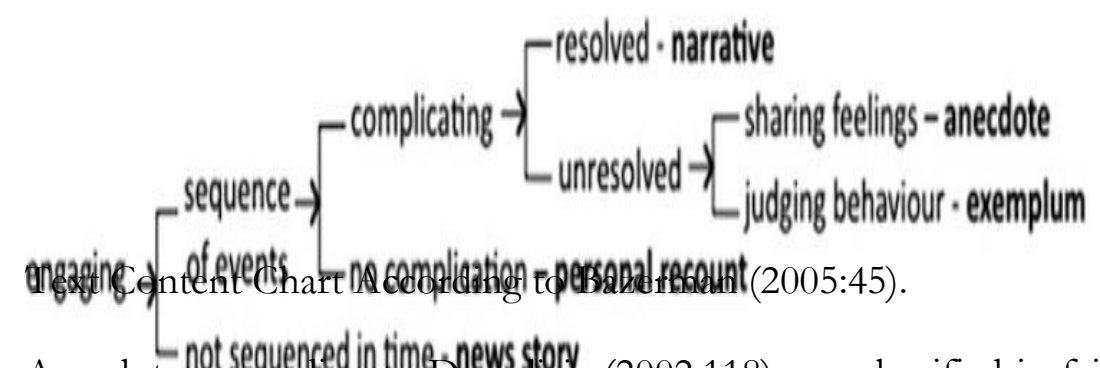

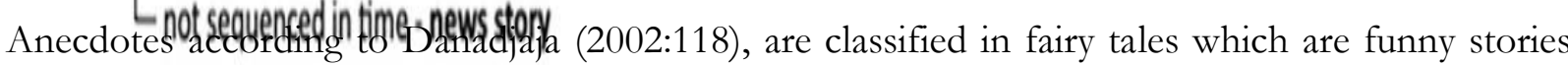
about the personalities of a figure or several figures who can be fictional or truly exist. This story is relatively short and interesting because it is funny, impressive, even ridiculous.

\section{Anecdotal "Kiud" Text Structure}

The Kiud story is classified in the anecdote of stories of a man or boy (stories about a man). This anecdote is about a young man named Kiud who was known as a young man who was lying or deceptive, so he was not liked by the entire village community where he lived. This anecdotal text structure consists of (1) abstraction, (2) orientation, (3) crisis, (4) reaction, and (5) coda.

The story begins with the introduction of a youth figure named Kiud in the abstraction section, then continues with an overview of the atmosphere or situation that will occur in the orientation section. After that, the crisis began to occur due to the silliness in the story and the ingenuity of the character of the Kiud, then continued with a reaction from the village head as a result of the crisis, and ended with the death of all male figures due to the ignorance and silliness shown in anecdotal stories this. The description of the structure of the anecdotal text of the Kiud is as follows.

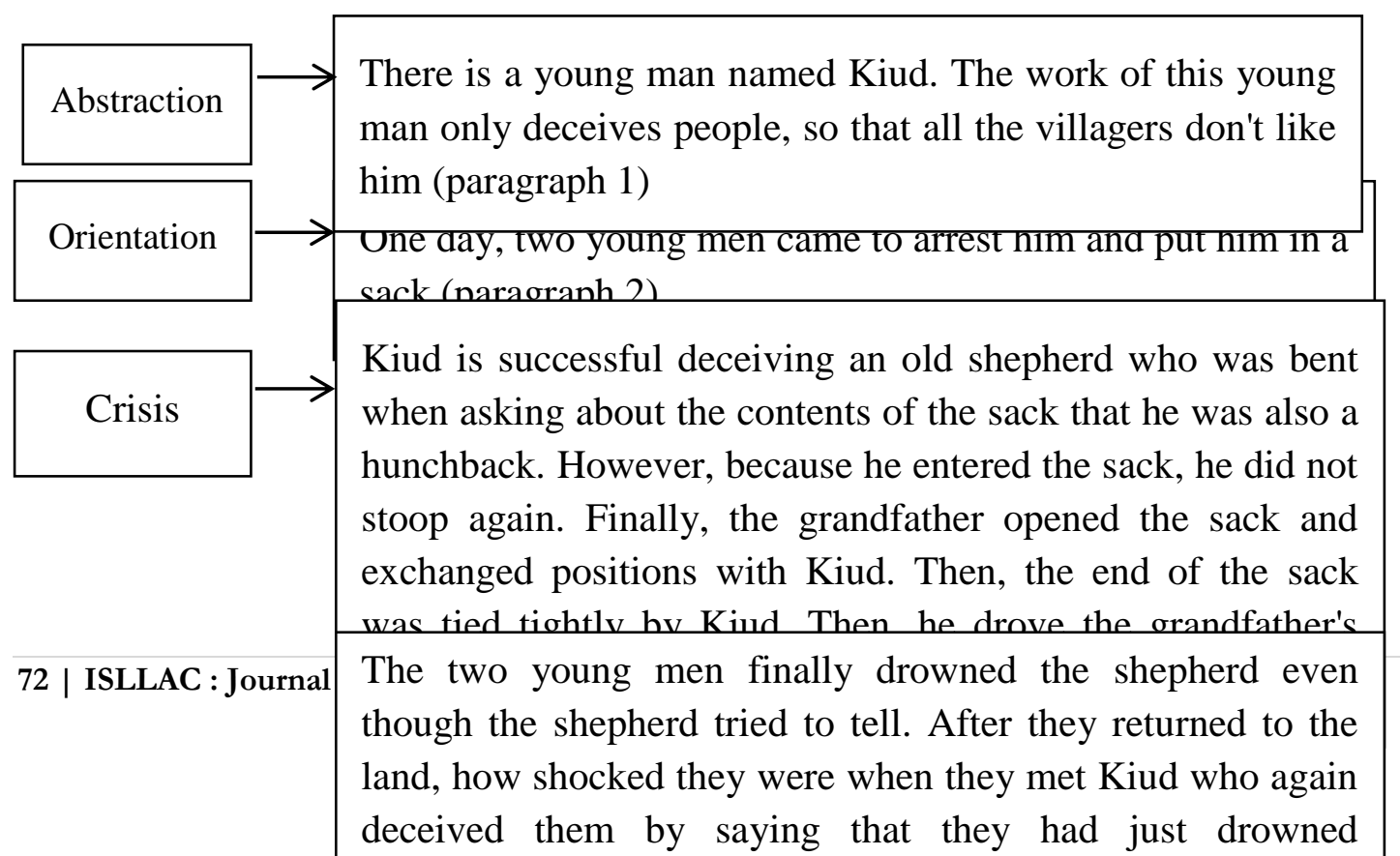




They said to Kiud, "Oh, then take us to the sea and deliver us
one hundred feet deep so that we will bring one hundred
sheep back." Then, the Kiud answered them, "The important

Representation of Siminess and Cuteness

The representation of the silliness and cuteness of the Kiud anecdotal text as follows:

- A hunchback person can walk normally if he enters a sack

This story describes something that is unreasonable or unacceptable in common sense. This aspect shows the silliness of this anecdotal text. The figure of the old shepherd in this story behaves foolishly easily fooled into something that is impossible, namely changing the shape of a hunchbacked body to return to normal by entering a sack.

Meanwbile, a bunchbacked old shepherd delivered a flock of sheep.

Ask the shepherd. "What's inside this sack?"

Then Kind said to the shepherd, "Yes grandfather, I am also a hunchback, but, because

I entered this sack, I am no longer bent. Try grandpa to open this bag, then go inside"

The shepherd began to open the sack and Kiud came out. The shepherd entered the sack. Then, the end of the sack was tied tightly by Kiud. hen, he drove the grandfather's flock away from the place.

\section{- An innocent person is sunk into the sea}

The silliness aspect represented in this anecdotal text is that the person who is considered guilty is not punished, but the innocent are punished. This can be seen in the following quote

Not long after, the two young men who had brought up earlier returned. They began to lift the sack and go to the beach. The old shepherd inside the sack began to scream, "Oh, I'm not Kiud. I'm not a Kiud. "However, the two young men said. "Shut up! Don't speak! "... They drowned him with stones.

- The depth of the sea represents the total of sheep that will be obtained

Another ridiculous thing that is represented in this anecdotal text is the depth of the sea when someone who is put into a sack then drowned in the sea will produce a large amount of sheep instead, and that person will safely return to the land with the sheep he got. This ridiculous thing can be seen in the following quote.

Then Kind answered them. "You drowned me into the sea, which was seventy fathoms deep, so I returned with seventy sheep."They said to Kiud, "Oh, then take us to the sea and deliver us one hundred feet deep so that we will bring one hundred sheep back." 
- Smart people can survive the dangers that will overflow

As a result of the ingenuity of the character of the Kiud, he finally managed to escape death which will overflow. But unfortunately, finally, the innocent old shepherd was drowned in the sea, even though he had tried to be honest. Here's the quote.

\section{The shepherd began to open the sack and Kiud came out. The shepherd entered the sack. Then, the end of the sack was tied tightly by Kiud. Then, he drove the grandfather's flock away from the place.}

\section{Value of Character Education in Kiud Anecdotal Texts}

The text of the Kiud anecdote even contains ridiculousness, but it cannot be denied that this text contains various teachings that can shape the character of the child. Stories and stories related to character education require children to be critical and reflect on their stories, so they can find moral messages from the content of stories that have the theme of character education. Folk stories also have five social functions, including developing community integrity, social control, strengthening solidarity and communal harmonization. Thus, acculturation of character education is an early way to prepare children's ways of thinking, behaving and behaving to anticipate changes in the life order that begin to lead to moral decadence (Amin, 2013: 31; Sahlan and Prastyo, 2012: 58).

Characters that can be developed for children include ethical values such as caring, honesty, compassion, kindness, empathy, justice, responsibility, and respect for oneself and others, citizenship, courage, honesty and trust, integrity, leadership, perseverance in building and achieving goals, respect, teamwork and cooperation (Fahmi, et al. 2017: 194; Almerico, 2014: 6; Berkowitz and Hoppe. 2009: 132; Elias, 2009: 833; Lickona, Schaps, and Lewis, 2007: 1-4).

The value of character education contained in Kiud's anecdotal texts is as follows:

\section{Courtesy Value}

The value of politeness in Kiud anecdotal text is illustrated in the attitude of the character Kiud and the old shepherd who greet people and ask questions about something they have just encountered. reply to the greeting of the interlocutor and answer the questions submitted, ask for approval from the other person, and ask for approval from people who are more powerful or have power.

\section{Value of Intelligence in Language}

The value of intelligence in language can be seen from every dialogue put forward by the figure of Kiud, which is to use language that is polite and clever in choosing expressions in the language.

\section{Value Ingenuity}

Even though the Kiud figure is told as a deceptive figure, it turns out that he has a clever attitude. With his ingenuity, he was able to save himself from danger.

\section{Value of Courage}

Kiud figures also have a brave attitude. This attitude can be seen when he meets again with two people who arrested him. Kiud was not scared or nervous when it was discovered that he was still alive, but with courage, he could dodge to survive danger.

\section{Critical Values in Addressing a Problem}

The polite, clever, and courageous attitude displayed by the character Kid, as well as being skilled in language, shows the critical attitude of the Kiud character when facing a problem.

Thus, anecdotes as part of a fairy tale turned out to provide many benefits to the formation of children's character. This is in line with the opinion of Noor (2011: 48), which states that fairy tales are able to print children who love reading, dare to speak, are able to express stories, and are able to create other tales. 


\section{CONCLUSION}

A silly or absurd thing in a fairy tale, according to some people, is a stupid thing that is done without using logic. However, when examined further, it turns out that fairy tales contain values that can shape a child's character.

Anecdotal fairy tales cannot be underestimated or compared to children's stories that are serious but must get the same position, which is used as a material for stories to children because, by storytelling, we teach children to love reading, dare to speak, and be critical in addressing a problem.

The anecdotal text of the Kiud has a structure ranging from abstraction, orientation, crisis, reaction, and coda. Silliness aspects are shown, among others, a hunchback person can walk normally if he enters a sack, an innocent person is drowned into the sea, inside the sea represents the number of sheep that will be obtained, clever people can survive the danger that will overflow. Character values that can be used to shape children's character consist of politeness values, intelligence values in language, the value of ingenuity, the value of courage, and critical values in addressing a problem.

\section{REFERENCES}

Albertus, D. K. (2012). Pendidikan Karakter Utub dan Menyeluruh. Yogyakarta: Kanisius

Almerico, G. M. (2014). Building Character Through Literacy With Children's Literature. Higher Education Journal. 26, 1-13

Amin, I dan Syahrul R. E. (2013). Cerita Rakyat Penamaan Desa Di Kerinci: Kategori dan Fungsi Sosial Teks. Jurnal Bahasa, Sastra, dan Pembelajaran, Vol. 1 (1), 31-41

Bazerman, C, et al. (2005). Reference Guide to Writing Across the Curriculum. Indiana: Parlor Press

Bendix, R. F, and Rokem, G. H. (2012). Concepts and Phenomena. dalam Regina F. Bendix \& Galit Hasan Rokem, (Ed.) A Companion to Folklore (pp. 7-12), Oxford: Wiley-Blackwell

Brunvand, J. H. (1996). American Folklore An Encyclopedia. New York: Garland Publishing

Danandjaja, J. (1994). Folklor Indonesia. Ilmu Gosip, Dongeng, dan lain-Lain. Jakarta: Pustaka Utama Grafiti

Chandra, N. E., \& Suyitno, I. (2017). The Representation of Character Education on Teachers' Utterances in Early Childhood Learning. ISLLAC : Journal of Intensive Studies on Language, Literature, Art, and Culture, 1(2), 53-63.

Finnegan, Ruth. (1992). Oral Traditions And The Verbal Arts. A Guide To Research Practices. New York: Routledge

Heryadi, Dedi. (2010). Metode Penelitian Pendidikan Bahasa. Bandung: PUSBILL

Miles, Matthew B. \& Huberman, A. Michael. (1992). Analisis Data Kualitatif. Buku Sumber Tentang Matode-Metode Baru. Jakarta: UI- Press

Noor, Rohinah M. (2011). Pendidikan Karakter Berbasis Sastra. Solusi Pendidikan Moral Yang Efektif. Yogyakarta: Ar-Ruzz Media

Noyes, D. (2012). The Social Base of Folklore. dalam Regina F. Bendix \& Galit Hasan Rokem, (Ed.) $A$ Companion to Folklore (hlm. 13-39), Oxford: Wiley-Blackwell

Park, N. 2009. Building Strengths of Character: Keys to Positive Youth Development. Reclaiming Children and Youth, Vol. 18 (1), 42-47

Sahlan, A and Prastyo, A. T. (2012). Desain Pembelajaran Berbasis Pendidikan Karakter. Yogyakarta: Ar-Ruzz Media

Samloy, S, et al. (1998). Lampiran cerita KIUD dalam Buku Struktur Babasa Kisar. Jakarta: Pusat Pembinaan dan Pengembangan Bahasa

Sibarani, R. (2012). Kearifan Lokal. Hakikat, Peran, dan Metode Tradisi Lisan. Jakarta: Asosiasi Tradisi Lisan

Sugiantomas, A dan Damayanti, W. (2017). Struktur Teks Anekdot Bertema Politik Dalam Buku "Gus

Dur Ku Gus Dur Anda Gus Dur Kita” Karya Muhammad As Hikam Sebagai Alternatif Pemilihan

Bahan Ajar Bahasa Indonesia Di SMA. FON Jurnal Pendidikan Bahasa dan Sastra Indonesia. Vol 11

(2), 136-143Chandra, N. E., \& Suyitno, I. (2017). The Representation of Character Education on

Teachers' Utterances in Early Childhood Learning. ISLLAC : Journal of Intensive Studies on Language, Literature, Art, and Culture, 1(2), 53-63.

Zuhdi, S, et al. (2015). Sejarah Dan Tradisi Lisan Orang Tanimbar. Suatu Pemetaan Memori Kolektif Sebagai Perekat dan Identitas Masyarakat Kepulauan. Ambon: Balai Pelestarian Nilai Budaya Ambon 